\title{
CYBER AGGRESSORS, THEIR MOTIVES, EMOTIONS AND BEHAVIOURAL TENDENCIES IN THE PROCESS OF CYBERBULLYING
}

\section{aVLADIMÍRA HLADÍKOVÁ, 'SABÍNA GÁLIKOVÁ TOLNAIOVÁ}

Faculty of Mass Media Communication, University of Ss. Cyril and Methodius in Trnava, Nám. J. Herdu, 2, 91701 Trnava email: ${ }^{a}$ vladimira.hladikova@ucm.sk, ${ }^{b}$ sabina.galikova.tolnaiova @ucm.sk

Abstract: The contribution focuses on the risk aspects of digital communication in cyberspace with a specific emphasis on bullying and has a theoretical-empirical character. The authors focused on the theoretical reflection of cyber aggressors, presenting number of definitional framework in the context of addressing issues of domestic and foreign authors. The main part of the contribution is focused on the results of the research aimed at the personality of cyber aggressors, their motives, experienced emotions and behavioural tendencies in the cyberbullying process. An important part of the contribution represents authentic statements of cyber aggressors contracted in various contexts. In conclusion, the authors emphasize the importance of prevention and elimination activities, as well as media and digital literacy, which would help to reduce negative phenomena in the digital environment.

Keywords: cyberbullying, cyber aggressor, victim, emotions, behaviour, research.

\section{Introduction}

Bullying through digital media and information and communication technologies is basically one of the forms of undesirable aggression and violence in interpersonal relationships. 'Such so-called cyberbullying is realized by actors - cyber aggressors in the context of certain motives and experiencing different emotions. The main aim of this contribution is to identify the personality of cyber aggressors through the theoretical background and obtained data of empirical research, to map their motives and tendencies of behaviour and actions in connection with the realization of cyberbullying. We used several qualitative and quantitative methods to achieve this goal. Phenomenological and hermeneutic methods are used in the theoretical part, or level of work, the method of self-construction questionnaire dominates in the empirical part. Other general logic methods are also used. The results of the research are shown in graphical overviews. In our opinion, the presented authentic statements of cyber aggressors in various contexts, which we perceive as important data obtained, can be considered as a specific part of research. In conclusion, the contribution reflects on the importance of preventing and eliminating the negative behaviour and actions of cyber aggressors as well as prevention activities (not only) in cyberspace.

\section{Cyber aggressor}

When it comes to bullying and its actors, they are most often divided into three basic groups - victims, aggressors and viewers, and especially in the case of victims and aggressors the emphasis is mainly on their personality characteristics. The terms "victim" and "aggressor" may then tend to suggest that certain children and adolescents are, by their very nature or appearance, disposed to be weaker and victimized, while others have characteristics that predestine them as attackers. However, A. Černá ${ }^{2}$ points out that cyberbullying is a group phenomenon. In addition to personality characteristics, most influential in the occurrence of this phenomenon are mainly dysfunctional relationships of given group or team. Other important factors are also the social roles and positions of actors, group norms and the structure and processes of the group. H. Macháčková-L. Dédková $^{3}$ also holds a similar opinion and say that it is in the collective that disturbed relationships or norms manifest

\footnotetext{
In the cyberspace of digital media, one projects both his positive and negative sides. Cyberspace becomes a kind of "mirror" of man. On this, please see: Galik, S.: On Human Identity of Cyberspace of Digital Media. In European Journal of Transformation Studies. Vol. 7, 2019, No. 2, p. 42.

2 Černá, A.: Online obtěžování a kyberšikana. In Ševč́́ková, A. et al.: Děti a dospivajicí online. Vybraná rizika použivání internetu. Praha: Grada, 2014, p.129. ${ }_{3}^{3}$ Macháćková, H., Dědková, L.: Aktéři kyberšikany. In Černá, A. et al.: Kyberšikana Průvodce novým fenoménem. Praha: Grada, 2013, p. 55.
}

themselves in some way, which can result in bullying. In describing cyberbullying, they particularly emphasize witnesses who are perforce involved in this process and the overall social environment in which cyberbullying takes place.

An interesting classification of cyberbullying actors is offered by the Slovak cyberbullying expert K. Hollá ${ }^{4}$, who divides them into six categories:

1. cyber aggressor (or cyber tyran);

2. a combined aggressor, i.e. person who conducts both offline and online bullying;

3. aggressive cyber victim, that can be both cyber aggressor and cyber victim simultaneously;

4. passive cyber victim;

5. a false cyber victim who is not a victim in the true sense of the word but a person of an aggressor/persecutor who pretends to be a victim;

6. watchers and supporters.

Aggressors (perpetrators, attackers) of electronic bullying can also be termed e-aggressors. The notion describes a man aggressively acting and at the same time drawing attention to the way of manifestation through technology. As regards the aggressors, M.R. Kohut ${ }^{5}$ says: "Apart from sophisticated technologies, cyberbullying is no different from traditional bullying by an aggressor. As in any other form of bullying, the aim is the same: to hurt, frighten and humiliate the victim either publicly or in private". In cyberbullying, however, aggressors are offered more powerful and insidious weapons in the form of ICT resources.

The aggressor's personality is formed during his ontogenesis. $\mathrm{K}$. Hollá $^{6}$ refers to E. Jaššová, who points out that most child aggressors use their physical superiority, maturity, which facilitates their aggressiveness. This kind of self-promotion tends to be more common in children who lack other possibilities of attracting attention, who lack different qualities and have a narrower range of interests. They may have a lot of energy, but it is not directed and they find their venting in aggressiveness. Some aggressors may act as extroverts with the tendency to entertain the collective at the expense of others. In cyberbullying, however, physical strength does not matter. Talking about cyber aggressors, they may not be individuals who are more socially skilful in the real world; on the contrary, they may be people who are shy in real life, lack assertiveness and are unable to relate to others. Cyberspace gives them the opportunity to be active or even aggressive. For individuals who are considered physically or socially disadvantaged, the virtual environment can also be a force due to anonymity and greater skills in handling technology. It does not matter age, gender, strength and social status, or real life achievements. In addition to anonymity, the absence of visual and auditory feedback can also have a negative impact on cyberbullying. By not seeing his/hers victim, the aggressor is unable to assess the consequences of his/hers actions, both affective and cognitive. As reported by M. Vašutová et al. ${ }^{7}$, empathy and set internal limits with limited contact, or lack of feedback significantly decimates. N. Willard ${ }^{8}$ has a similar view and says that "when a young aggressor sees rejection as a response of others' to his aggressive behaviour, this knowledge can lead him to feel

\footnotetext{
${ }^{4}$ Hollá, K.: Sexting a kyberšikana. Bratislava: Iris, 2016, p.34.

${ }^{5}$ Kohut, M.: The complete guide to understanding, controlling, and stopping bullies: a complete guide for teachers \& parents. US, Florida, Ocala: Atlantis Publish Group, 2008, p. 26.

${ }^{6}$ Hollá, K.: Elektronické šikanovanie: nová forma agresie. Bratislava: Iris, 2010, p. ${ }^{2} 8$.

${ }^{2}$ Vašutová, M. et al.: Proměny šikany ve světě nových médii. Ostrava: FF Ostravské univerzity v Ostravě, 2010, p. 91

${ }^{8}$ Willard, N.: Cyberbullying and cyber threats: responding to the challenge of online social aggression, threats, and mistress. Champaign: Research Press, 2007, p.76.
} 
shame, "face loss",". A. Černá ${ }^{9}$ adds in this regard that for aggressors of any bullying, there is a common low level of empathy compared to others. They are thus unable to empathize with the victim and understand the injuries they cause. For cyberbullying, this phenomenon will stand out even more - it relates to so-called cockpit effect (Heirman, Walrave, 2008) - an alignment based on World War II pilots dropping bombs on the civilian population. People seemed so distant and unrealistic from the cockpit that they did not even consider them and the suffering they caused. Similarly, the cyber aggressor does not see his/hers victim and his/hers reactions and does not estimate how much harm he or she could cause.

Thus, we can call a cyber aggressor a person who has no guilt, is not worried about hurting someone. He or she does not consider his/hers actions immoral and often blames the victim. Cyberbullying aggressors can be divided into active and passive ${ }^{10}$. An active e-aggressor is a person who in many situations reacts aggressively, has a positive relationship to violence and a strong need to control others. A passive eaggressor is loyal to the suffering of others and often becomes an accomplice in bullying others.

Different styles of cyberbullying are typical for different types of cyber aggressors. They also differ in the motives of their behaviour, the ways they hide or spread their activities. A. Kavalír eds. ${ }^{11}$ classifies four types of cyber aggressors as follows:

- The type of so-called "vengeful angel"- it is typical of this type that he or she does not perceive himself/herself as an aggressor. He or she sees himself/herself as a person who corrects evil and protects himself/herself and others from the "villain"-his or her victim. This includes people who often become aggressors for two reasons. In the first case, because they themselves were victims of offline or cyberbullying and feel they have the right to avenge others for what they had to survive. The second case concerns people trying to protect a friend who was bullied. These types are mostly bullying on their own, but can involve others in their activities. They want to take justice into their own hands.

- The type of power-hungry aggressor -they are those who exercise authority and power, want to demonstrate their strength. They desire to control others through fear and often need an audience they boast about. If they do not receive sufficient response, praise, the attacks intensify. Interestingly, the actors are often girls, less physically fit, disliked children. However, they show greater technical skills. Their intention is to frighten and shame victims, which is enabled by the anonymous environment of cyberspace and the fact that they cannot directly confront the victims. They look harsh, rough, but in reality they are not. Due to the features described above, these may be the most dangerous type of cyber aggressors of all.

- The type of spoiled girls -those are mostly girls who are bored, looking for distraction and fun. Most often bullying other girls on a whim. Cyberbullying is usually for fun and requires an audience. Their activities shall cease if the actors and prospectors do not get the appropriate entertainment they expected from their actions.

- The type of unintentional aggressor-they are not necessarily aggressors in the true sense of the word. They react disproportionately to a hateful, provocative attack, unaware of the consequences of their actions. They may feel injured or angry; tend to react to anger and frustration. They don't think about their actions before clicking the "send" button. They are unaware of the magnitude of cyberbullying, experimenting and doing individual deeds often for fun or simply because they "can".

\footnotetext{
9 Černá, A.: Online obtěžování a kyberšikana. In Ševčíková, A. et al.: Děti a dospivajicí online. Vybraná rizika použivání internetu. Praha: Grada, 2014, p. 133. ${ }^{10}$ Hollá, K.: Elektronické śikanovanie: nová forma agresie. Bratislava: Iris, 2010, p. ${ }^{29}$.

${ }^{21}$ Kavalír, A. (eds.): Kyberšikana a jejíprevence - príručka pro učitele. Plzeň: Člověk v tísni o.p.s., 2009, p. 19-21.
}

It is also interesting to mention briefly the characteristics of the cyber aggressor in terms of gender. Cyberbullying studies do not provide adequate gender differences between e-aggressors. Some authors state no significant changes and argue that gender is not a significant predictor of involvement in cyberbullying. Analysis of N.A. Card et al (2008) brought findings that boys are more physically aggressive and include physical attacks in individual forms of bullying (e.g. threats of physical violence through electronic communication, happy slapping, etc.). Girls have strong verbal abilities and can make attacks through text messages. However, gender differences are less different in cyberbullying than in traditional bullying. Any differences may be due to different ways of using the Internet and online activities. For example, boys play games more often, so they can be victims of direct cyberbullying - flaming, insultsor abuse. Girls are more likely to engage in social activities - they communicate, read, blog, contribute to discussions - they may encounter an indirect form of cyberbullying, e.g. forwarding emails, identity theft, defamation, slander, etc. ${ }^{12} \mathrm{~K}$. Hollá ${ }^{13}$ adds that, from a gender perspective, boys are more likely to become cyber aggressors, as they have greater technical skills with complex Internet applications. However, this finding does not exclude girls from committing this socio-pathological phenomenon, as female aggressors choose this form of violence because of the anonymity of cyberspace and the low possibility of real confrontation.

\section{Research methodology}

We consider the issues discussed at the beginning of this contribution to be extremely topical and interesting. In examining these contexts, we decided to use a quantitative research strategy as it results in diverse data. The basic tool of quantitative research was a questionnaire of our own construction, which contained 51 questions of various characters. In the evaluation and interpretation of research results were used methods of analysis, synthesis, comparison, methods of statistical data processing and their testing, as well as generalization of data or their graphical representation.

The research was focused primarily on high school students, who also formed the object of our research. Questionnaire categories, their content, form and wording were also adapted to respondents' age. In order for the research to achieve relevant and interesting results, our aim was to seek as many respondents as possible. We set a minimum limit of 500 students of both genders. The lower age limit was 14 years; the upper age limit was 20 years. The research was carried out in the region of Trnava.

Since the research carried out was exploratory in nature (we examined the experience, consequences, attitudes and possibilities of protection and prevention from the perspective of cyberbullying victims), we did not formulate hypotheses in this case, but on the basis of comparison of literature and research of discussed problems up to now, we followed several assumptions. The following three selected assumptions are important for the purpose of this contribution:

1. We assume that the most frequent form of cyberbullying among the implementers was identity theft.

2. We assume that the most common reason for cyberbullying is the revenge of cyber aggressor.

3. We assume that cyber aggressors most commonly committed bullying through social networking sites.

We then digitized all print versions of the questionnaires and respondents' answers into electronic form. The electronic questionnaire was created through Google, which we used to process more accurate and thorough results. The obtained data were tested, analysed, evaluated and we have drawn certain

\footnotetext{
${ }^{12}$ Macháčková, H., Dědková, L.: Aktéři kyberšikany. In Černá, A. et al.: Kyberšikana. Prưvodce novým fenoménem. Praha: Grada, 2013, p. 68 Průvodce novým fenoménem. Praha: Grada, 2013, p. 68.
${ }^{13}$ Hollá, K.: Kyberšikana. Bratislava: Iris, 2013, p. 34.
} 
conclusions and opinions from them that we present in the next chapter of the contribution.

\section{Interpretation of research results}

The first part of the questionnaire was devoted to the demographic data of respondents (gender, age, level of education). 775 respondents, both genders, participated in the research. However, some questionnaires were not returned, fully completed or could not be used and included in the research sample for other reasons. The rate of return of the questionnaires is $\mathbf{8 6 . 1} \%$, which we consider a success. The following graphs report the identification data of the respondents who participated in our research.

Graph 1: Gender of respondents

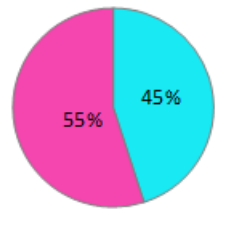

Source: Own processing

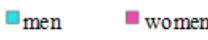

Graph 2: Age of respondents

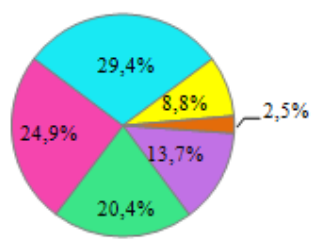

$\because 15 \quad 16 \quad=17 \quad \square 18 \quad \square 19 \quad=20$

Source: Own processing

Graph 3: Type of high school

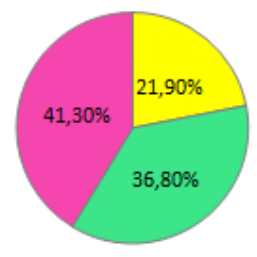

$\square \mathrm{SOU} \quad \mathrm{SOS}=\mathrm{GYM}$

Source: Own processing

In addition to the identification data, we also identified some of the respondents' preferences in the context of spending time in cyberspace or the communication platforms they use there. It should be noted that respondents had the opportunity to indicate more response options for most questions in the questionnaire. We can say that more than $71 \%$ of respondents spend four or more hours on the Internet every day. We consider this to be highly alarming, as several authors point out that being online for more than three hours a day can have a significantly negative, even pathological impact on children and juveniles.

In the following part of the contribution, due to the limited scope and the large amount of data obtained, we will interpret only a selected area of research, which focused exclusively on implementers of electronic bullying, their motives, experienced emotions or behavioural tendencies and actions, and other contexts related to this phenomenon (q. no. 42-51 in questionnaire). The research results show that up to $20.9 \%$ of the research sample, which represents 162 respondents belongs to this group. As the respondents may have had multiple experiences of realizing different forms of cyberbullying, they could respond by marking multiple options.
Graph 4: The forms of cyberbullying realized by aggressors

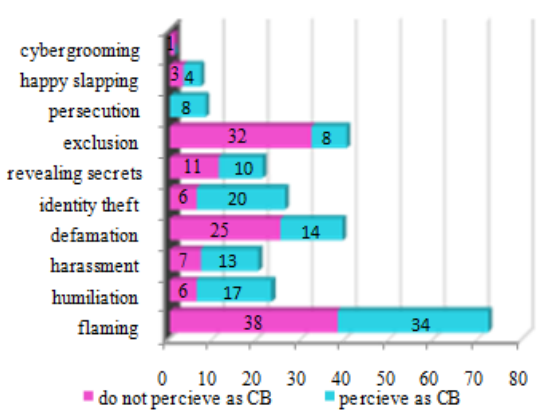

Source: Own processing

Graph 4 shows the number of respondents who implemented different forms of cyberbullying, as well as the difference in who considers or does not consider their behaviour as being identical to electronic bullying. For offenders, we included two separate questions in the graph. In Question 42 we asked whether respondents in their opinion became the perpetrators of cyberbullying, 68 respondents answered positively, which represents $8.8 \%$ of the research sample. In Question 43, we investigated whether they implemented any type of behaviour on the Internet towards other persons, while not using the notion of cyberbullying (or its forms). With this question, we wanted to see what the respondents perceive as cyberbullying and whether they are aware that they have become such aggressors. Up to 162 respondents answered positively in Question 43, which represents almost $21 \%$ of the research sample. The most common forms of cyberbullying that e-aggressors used in cyberspace include flaming $(44.4 \%)$, exclusion from online groups $(24.7 \%)$, defamation $(24.1 \%)$ and imitation, use and theft of foreign identity $(16 \%)$.We assume that flaming and exclusion was identified by most respondents because they are either digital game players and/or members of certain specific virtual communities, where these two types of actions are easiest to accomplish. What is interesting is the difference between whether the perpetrators are aware that they have implemented a certain type of cyberbullying. While in flaming, the ratio between those who evaluate their behaviour as cyberbullying and those who do not evaluate their behaviour as cyberbullying is fairly balanced ( 38 respondents do not perceive as cyberbullying, 34 perceive as cyberbullying), when excluded from online groups, up to four times the perpetrators do not perceive this phenomenon as a form or manifestation of cyberbullying in proportion to those who deliberately implemented the exclusion as cyberbullying. This disproportion may be due to the fact that in gaming communities it is possible that behaviours such as flaming or ostracization and exclusion are to some extent considered a normal component and natural phenomena in this environment. This is confirmed by the interesting commentary of one of such aggressors, which we present in the original version: "Flame in small quantities does not cause any malice in person, I do not consider it bullying. I know I do not cause them any harm and in my group this is more of a form of deepening friendship". Therefore, most implementers do not seem to realize that it is in fact a real form of negative and inappropriate behaviour in cyberspace. This is also confirmed by the outcome of Question 16, where nearly $19 \%$ of respondents said cyberbullying is a common part of the Internet.

We determined a different situation in identity theft; where out of 26 respondents who implemented this action, up to 20 of them realize that this is cyberbullying. It follows that they chose this form deliberately with the aim of harming the victims and clearly causing them problems. The fact that such a significant difference between awareness and ignorance of cyberbullying was proven precisely when imitating and using the identity of others may be related to the fact, that it is possible to realize this form almost exclusively in cyberspace. It offers offenders many options and weapons to deliberately harm or threaten victims. In the persecution, we even found that all who confessed to its 
implementation are aware of and evaluate their behaviour as cyberbullying with the intention of hurting others. The least realized form in our research is cybergrooming, which was used only by one respondent. Cybergrooming is mostly associated with older Internet users who target child victims and abuse. Happy slapping was actively performed by 7 students, while the cyberbullying non/awareness rate is approximately the same. However, this number is relatively high. Given that there have been many cases of happy slapping and media coverage recently, we feel that this highly negative and dangerous phenomenon is starting to take place increasingly among young people and that the pain and suffering of victims is spreading virally (especially via YouTube). At the same time, it can be stated here that the Assumption 1 that the most frequent form of cyberbullying among the implementers was identity theft was not confirmed.

To clarify the circumstances of cyberbullying, we also focused on the motivation of the attackers to implement selected forms of bullying. The desire for entertainment $(33.5 \%)$ led the eaggressors to action most often. Almost the same number of respondents committed cyberbullying because the victim deserved it $(32.9 \%)$. Other notable motivational factors were revenge $(26.1 \%)$, anger $(20.5 \%)$ and absence of fear of action consequences (20\%). These results are similar to those in question 16 , where over $20 \%$ of respondents said they perceived cyberbullying as a fun or a way of revenge. The slightly less tendency to activity was caused by the same experiences with cyberbullying, the ease of realization, the desire for power, the coolness or the jealousy. In this context, we can state concrete statements by the respondents-aggressors about what led them to do so: "I was bullying because the person was doing exactly the same thing to me until I got up to it"; "Although I hurt someone, it was not meant bad, I just wanted him/her to feel the way I felt when he/she hurt me and realized he/she was making a big mistake"; "People will do everything to return what the other deserves"; "If someone is being bullied, whether in real life or on the Internet, I think it is just his/hers fault that he/she cannot defend himself/herself." Exact data of individual motivating factors of e-aggressors are shown in Graph 5. Research results suggest that Assumption 2 that the most common reason for cyberbullying is the revenge of cyber aggressors was only partially confirmed, as revenge as a motive for aggressive behaviour is among the three most cited initiating reasons for cyberbullying.

Graph 5: Motivation of cyberbullying implementers

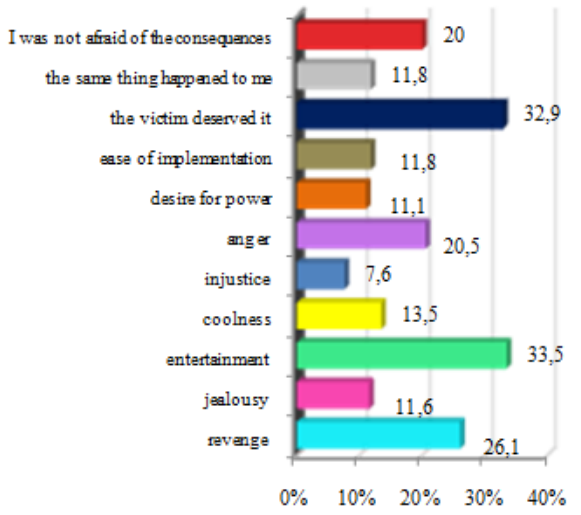

Source: Own processing

Attention was also paid to identifying traits of the perpetrators, and to choosing a username in cyberbullying. We have found that more than half of e-aggressors $(54.1 \%)$ are cyberbullying under a fictional name. Almost $12 \%$ of the total number of attackers use a foreign name in the context of bullying on the Internet, most of which carry out identity theft. More than a third of all implementers are cyberbullying under their own name.
Graph 6: Names of e-aggressors

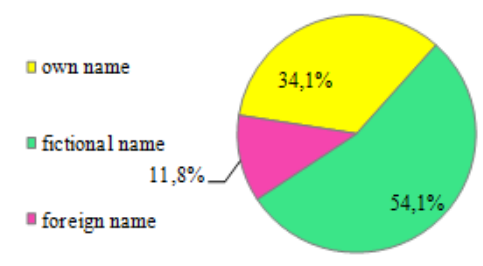

Source: Own processing

In the next step we tried to find out what feelings in cyberbullying implementers caused their actions. Also in this question, we offered the respondents the opportunity to mark multiple answers for a comprehensive statement, as we assumed that several different emotions culminated in e-aggressors. It is striking that over $94 \%$ of e-aggressors experienced positive emotions, namely satisfaction $(36.1 \%)$, joy (34.3\%) and redress $(23.7 \%)$. Another widespread feeling is nervousness described by almost $12 \%$ of the attackers. To a lesser extent, anxiety or fear of revelation is also present. Some respondents $(1.8 \%)$ even stated that their actions did not result in any emotions.

Graph 7: Emotions of e-aggressors

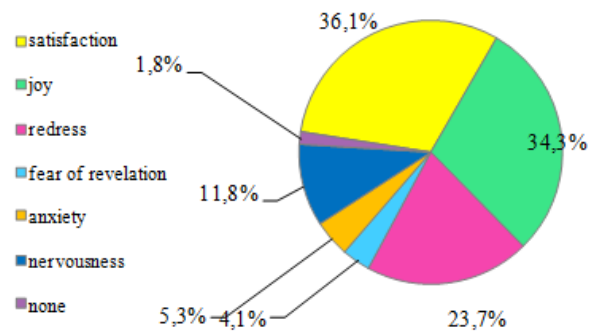

Source: Own processing

Within cyberbullying, it is also noteworthy the ending of this process; we have used Question 47 to map this issue. More than half of the e-aggressors stopped implementing cyberbullying of their own free will. $20.8 \%$ of the attackers put an end to bullying by external agents. After the fear of revelation, $11.8 \%$ of offenders did so, $5.3 \%$ of e-aggressors were directly revealed by another person, and $3.7 \%$ of the attackers admitted to cyberbullying because of the perceived pressure. Almost a quarter $(23.6 \%)$ of e-aggressors describes their actions as persistent.

Graph 8: The process of ending cyberbullying

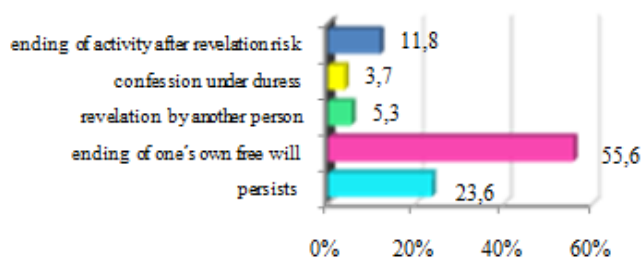

Source: Own processing

We were also interested in the relationship between the perpetrators of cyberbullying and their victims. An exceptionally high percentage $(71.3 \%)$ of the implementers said they bullied their acquaintances. As many as $32.7 \%$ of attackers cyberbullied classmates, $21 \%$ of attackers cyberbullied former friends, $10.5 \%$ cyberbullied expartners and $8 \%$ cyberbullied friends. Completely foreign people were bullied by $27.8 \%$ of e-aggressors. In addition to the relationship between cyberbullying actors, we also investigated whether the perpetrators had confided in their deeds and the conduct of these actions and found that up to $77.9 \%$ of e-aggressors were silent about cyberbullying. Of the other $22.1 \%$ of the actors, half of them admitted their behaviour 
to the group of friends. The other $11.05 \%$ of the perpetrators confessed publicly to the whole of their surroundings.

Similarly, as we wanted to know in the victims if the aggressive behaviour in some way transferred into reality, we also asked cyberbullying respondents in Question 50 about this. More than $35 \%$ said that somehow their aggression shifted to the real environment. Verbal attack was carried out by $23 \%$ of offenders, $12.5 \%$ of the attackers even carried out some physical attack on their victims. Research shows that people who tend to hurt others more often realize these attacks and aggression in cyberspace.

Graph 9: Transfer of cyberbullying to reality by aggressors

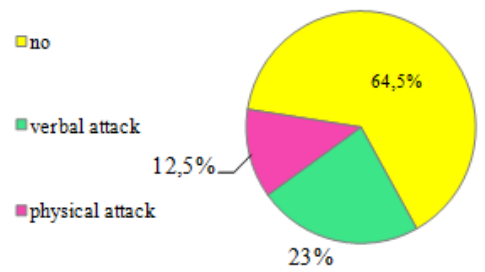

Source: Own processing

In analysing the situation of realization of cyber attacks in the context of offenders, in Question 39we also questioned the use of platforms in which cyberbullying occurred. Similarly to the victims, e-aggressors made the most of their attacks through social networking sites $(61.2 \%)$. The second "most popular" platform, according to the results of our research, is the IM messages, identified by $28.2 \%$ of respondents. In this context, we can also mention digital games, which were mentioned by $6.2 \%$ of respondents. More than $10 \%$ of aggressors reported negative behaviour on YouTube. We assume that these may be particularly unpleasant, offensive and slanderous comments under the videos of favourite youtubers, many of whom young people take as role models and idols. Therefore, they have a need to express themselves and protect them from possible "haters" who can describe their favourites in not too flattering light. The least used is e-mail communication $(1.8 \%)$, which is also related to the age of the research sample and we assume that they do not use e-mail very often. Social networking sites and IM messaging are what the young generation is most likely to use to communicate in cyberspace. However, as we can see, these communication platforms are also the space where various forms of electronic aggression are most often applied and implemented. The results of the research shown that the Assumption 3 that cyber aggressors most commonly committed bullying through social networking sites was confirmed.

Graph 10: Platforms used for cyberbullying by aggressors

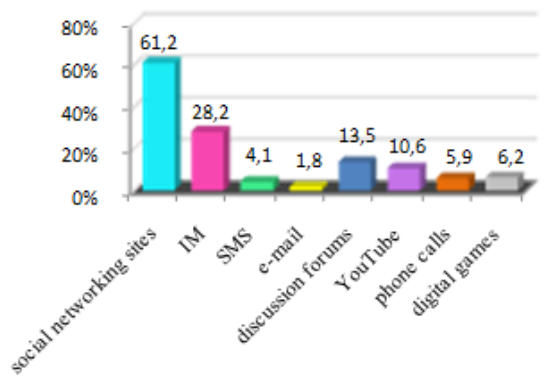

Source: Own processing

Lastly, with regard to the category of cyber victims and cyber aggressors, we decided to map, compare and interpret this categorization also in the context of traditional bullying. The results of our research show that, while 53 respondents were victims of traditional bullying, which represents $6.8 \%$ of the research sample, cyber victims are nearly $40 \%$ of the research sample. Similar results are also in the category of aggressors, with $3.6 \%$ of respondents becoming the perpetrators of traditional bullying and almost $21 \%$ of the research sample was cyber aggressors. In both categories, we can see that the increase in victims and aggressors is up to 5 times in cyberspace than in the real world. It is therefore very important to realize that cyberspace is becoming, besides many benefits, an environment with demonstrably increasing aggression and unwanted behaviour by some of its users, and these results cannot be ignored or overlooked.

Tab. 1: Comparison of the number of victims and aggressors in traditional bullying and cyberbullying

\begin{tabular}{|c|c|c|c|c|c|}
\hline $\begin{array}{c}\text { Traditional } \\
\text { bullying }\end{array}$ & $\mathbf{n}$ & $\boldsymbol{\%}$ & $\begin{array}{c}\text { Cyber } \\
\text { bullying }\end{array}$ & $\mathbf{n}$ & $\boldsymbol{\%}$ \\
\hline Victim & 53 & 6,8 & Victim & 294 & 37,9 \\
\hline Aggressor & 28 & 3,6 & Aggressor & 162 & 20,9 \\
\hline
\end{tabular}

Source: Own processing

\section{Conclusion}

We are currently experiencing a new social "digital" era in which we can hardly imagine our lives without information and communication technologies and digital media. These undoubtedly make life easier for us in many areas and change it for the better. They are an important source of information, news and knowledge ${ }^{14}$, and represent important opportunities for our personal and social interaction and communication.

It can be stated that important essential elements of communication between people undoubtedly include, whatever its form is, a certain degree of appropriate social behaviour and decency ${ }^{15}$, as well as security. Let us point out that cyberspace security is currently one of the most serious problems, because cyberspace currently provides almost unlimited possibilities for various forms of harming others in terms of communication. Cyberbullying is clearly one of them. It is a socio-pathological phenomenon that negatively affects individuals, families and ultimately society as a whole. It is also a serious psychological, moral and ethical problem, which as such requires adequate professional attention in society as well as a real effort to prevent and address it.

In order to tackle this problem successfully, especially in prevention, we consider it very important to identify cyberbullying, which takes place for many years and unfortunately without notice from the surroundings, especially parents or teachers. At the same time, it is essential that not only the professional but also the general public have sufficient information about this phenomenon, its nature and its manifestations by both the perpetrators and the victims. In this respect, it is important to provide institutional support to preventive information activities on cyberspace risks, as well as various projects, or societal research on them.

In this context, we believe that the family is the basic social environment in addition to the school that can, and should be most preventive in relation to the potential risk of cyberbullying. The use of appropriate techniques of parental mediation, building trusting relationships with children, cooperation of parents and schools on digital security issues, as well as autoeducation of parents in media and digital literacy and competences are factors that can have a significant impact on the elimination of various negatives in the context of cyberspace and hence cyberbullying. ${ }^{16}$

In conclusion, we would like to appeal to a consistent and responsible approach to the issue, since cyberbullying does not

\footnotetext{
${ }^{14}$ Gálik, S.: Influence of Cyberspace on Changes in Contemporary Education. In Communication Today, Vol. 8, 2017, No. 1, p. 37.

${ }^{5}$ Hladíková, V.: Ethics of electronic communication- knowledge and its application by primary school students. In SGEM 2016: 3rd International Multidisciplinary Scientific Conference on Social Sciences and Arts: Sociology and Healthcare. Volume II: Psychology and Psychiatry, Sociology and Healthcare, Education. Sofia: STEF92 Technology, 2016, p. 463.

${ }_{16}$ Educations in the area of media competences and media literacy are a relevant preparation for effective self-realization in cyberspace. It also ansers security preparation for effective self-realization in cyberspace. It also answers security questions in today's dynamic informe (2018), No. 2, p. 39.
} 
remain without the consequences, which are often tragic. Possibilities of its prevention and elimination are in our hands (at least to some extent and in some way). However, we emphasize the need for real cooperation between parents, educators and various experts, as well as the implementation of prevention projects and measures at regional, national and international level.

\section{Literature:}

1. Černá, A.: Online obtěžování a kyberšikana. In Ševčíková, A. et al.: Déti a dospivajici online. Vybraná rizika použivání internetu. Praha: Grada, 2014. pp. 119-142. ISBN 978-80-2475010-1.

2.Gálik,S.: Influence of Cyberspace on Changes in Contemporary Education. In Communication Today. Vol. 8 (2017), No. 1. pp. 30 - 38. ISSN 1338-130X.

3. Gálik, S.: On Human Identity of Cyberspace of Digital Media. In European Journal of Transformation Studies. Vol. 7 (2019), No. 2. pp. 33 - 44. ISSN 1338-130X.

4. Hladíková, V.: Ethics of electronic communicationknowledge and its application by primary school students. In SGEM 2016: 3rd International Multidisciplinary Scientific Conference on Social Sciences and Arts: Sociology and Healthcare. Volume II: Psychology and Psychiatry, Sociology and Healthcare, Education. Sofia: STEF92 Technology, 2016. pp. 463-470. ISBN 978-619-7105-71-1.

5. Hollá, K.: Elektronické šikanovanie: nová forma agresie. Bratislava: Iris, 2010.93 p. ISBN 978-80-89256-58-7.

6. Hollá, K.: Sexting a kyberšikana. Bratislava: Iris, 2016. 166 p. ISBN 978-80-8153-061-6.

7. Hollá, K.: Kyberšikana. Bratislava: Iris, 2013. 126 p. ISBN 978-80-8153-0111.

8. Kačinová, V.: Media competence as a cross-curricular competence. In Communication Today. Vol 9 (2018), No. 2. pp. 38-57. ISSN 1338-130X.

9. Kavalír, A. (eds.): Kyberšikana a její prevence - přiručka pro učitele. Plzeň: Člověk v tísni o.p.s., 2009. 104 p. ISBN 978-808696-178-1.

10. Kohut, M.: The complete guide to understanding, controlling, and stopping bullies: a complete guide for teachers \& parents. US, Florida, Ocala: Atlantis Publish Group, 2008. 288 p. ISBN 978-1601380210.

11. Macháčková, H., Dědková, L.: Aktéři kyberšikany. In Černá, A. et al.: Kyberšikana. Průvodce novým fenoménem. Praha: Grada, 2013. pp. 55-82. ISBN 978-80-247-4577-0.

12. Vašutová, M. et al.: Proměny šikany ve světě nových médií. Ostrava: FF Ostravské univerzity v Ostravě, 2010. 226 p. ISBN 978-80-7368-858-5.

13. Willard, N.: Cyberbullying and cyber threats: responding to the challenge of online social aggression, threats, and mistress. Champaign: Research Press, 2007. 311 p. ISBN 978-087-8225378 .

Primary Paper Section: A

Secondary Paper Section: AJ, AM, AN 